\title{
10. INTERPRETATIVE PERFORMANCES: ELISABETH LEONSKAYA AND PAUL BADURA-SKODA
}

Brînduşa Tudor ${ }^{97}$

\begin{abstract}
In the complex road of deciphering and understanding a musical work, an important step for the pianist (performer or professor) is represented by the choice of reference interpretations according to some famous musicians. Elisabeth Leonskaya and Paul Badura - Skoda are among the most distinguished representatives of the contemporary school of piano.
\end{abstract}

Key words: Elisabeth Leonskaya, Paul Badura - Skoda, interpretation, piano

\section{Introduction}

In the complex road of deciphering and understanding a musical work, an important step for a pianist (performer or professor) is represented by the choice of reference interpretations according to some famous musicians. Elisabeth Leonskaya and Paul Badura-Skoda are among the most distinguished representatives of the contemporary school of piano.

\section{Elisabeth Leonskaya - short biographical data}

Elisabeth Leonskaya is one of the most representative personalities of the Russian school of piano. Born on the $23^{\text {rd }}$ of November 1945 in Tbilisi, Georgia, in a family of Russian origin, Elisabeth Leonskaja was considered to be a wonder child; she had her first concert when she was 11 . While she was studying with Jacob Milstein from the Conservatory of Moscow, she was awarded prestigious prizes at the international piano competitions George Enescu Bucharest, Marguerite Long Paris and Queen Elisabeth Brussels. The performer's artistic cooperation with the pianist Sviatoslav Richter had an overwhelming influence on her musical development. Since the resonant debut within the Salzburg Festival of 1979, the pianist had a large number of recitals and held concerts with the world's great orchestras under the baton of the conductors Kurt Masur, Sir Colin Davis, Christoph Eschenbach, Maris Jansons and many others. She is also known due to her special chamber activity next to the quartets Alban Berg, Borodin, Guarnieri and Artemis. The large number of recordings and awarded prizes testify the remarkable artistic achievements of the pianist: Diapason d'Or (for the recordings of works by Franz Liszt) and Caecilia Prize (for the CD with the piano sonatas by Johannes Brahms). In 2006, Austria, her adoptive country, acknowledged her special merits brought to the cultural life, by offering her the highest distinction: The Austrian Cross of Honour, First Class.

\footnotetext{
${ }^{97}$ Lecturer PhD., “George Enescu” National University of Arts from Iaşi, Romania, email: tudorbrindusa@yahoo.com
} 


\section{Paul Badura-Skoda - short biographical data}

Born on the $6^{\text {th }}$ of October 1927 at Vienna, Paul Badura-Skoda is one of the most famous representatives of the Austrian school of piano. He started the courses at the Conservatory of Vienne in 1945 and received international recognition in 1947 when he ranked first at the Music Competition in Austria. On this occasion he also obtains a scholarship that allowed him to study with the famous pianist Edwin Fischer, the years spent under the guidance of this master representing the foundation of his artistic development. A very important part in launching of the artistic career of Paul Badura-Skoda was also played by the famous conductors Wilhelm Furtwängler and Herbert von Karajan who invited him to perform in concerts with them in 1949. Throughout the years the pianist held recitals on the world's greatest stages, he was invited to the most important music festivals and held concerts with the most famous orchestras under the baton of the conductors George Szell, Karl Böhm, Lorin Maazel, Zubin Mehta, Sir Charles Mackerras, Sir Georg Solti, Kent Nagano, John Eliot Gardiner etc. The discography career of Paul Badura-Skoda contains an impressing number of recordings at great record companies such as Westminster label, Deutsche Grammophon, Astreé, Arcana, Music\&Arts, Sanctuary Classics, Jecklin-Disc, Harminia Mundi etc. The approached repertoire is a broad one, the pianist's fame being especially related to the works belonging to the Viennese composers Wolfgang Amadeus Mozart, Ludwig van Beethoven and Franz Schubert, also including some complete cycles of sonatas. Paul Badura-Skoda is also known as a very valuable musicologist, his publications including Mozart-Interpretation (published together with his wife Eva Badura-Skoda, musicologist), BachInterpretation: Die Klavierwerke Johann Sebastian Bachs, Die Klavier Sonaten von Ludwig van Beethoven (published together with the Austrian pianist Jörg Demus), articles on Schubert, Chopin and may others, that came out in various German magazines specialising in music.

\section{Comparative analysis}

In order to highlight the creating genius of the two famous pianists, we chose for interpretative analysis model the Sonata in A major op. post. $120 \mathrm{D} 664$ by Franz Schubert. Elisabeth Leonskaja had this sonata recorded in 1993, at the record company Teldec Classics International GmbH. The CD also includes the Sonata in A major D 959. The interpretation of Paul Badura-Skoda had dated back to 1971 when the pianist had 20 piano sonatas by Franz Schubert recorded (it is the only pianist with such a large number of sonatas, according to our knowledge) at the record company RCA Victrola of America, and they consisted of four volumes: volume I - D 157, D 279, D 459, D 537, D 557, D 566; volume II - D 568, D 571, D 575, D 613, D 625, D 664; volume III - D 784, D 840, D 845, $D$ 859; volume IV - D 894, D 958, D 959, D 960. These CDs also contain the completions carried out by the pianist in case of the unfinished sonatas, as they appear in volume III of Henle edition, Urtext version ${ }^{98}$.

\footnotetext{
${ }^{98}$ Schubert, Franz - Klaviersonaten. Band III, Urtext, G. Henle Verlag, Munich
} 
First part, Allegro moderato (Elisabeth Leonskaja - 12'55", Paul BaduraSkoda - 6'58")

\section{Exposition}

The two performers have different views when it comes to choosing the tempo in which the first part takes place: Elisabeth Leonskaya prefers highlighting the lyrical side by a more settled tempo, therefore impregnating the musical discourse with a calm nature; Paul Badura-Skoda exposes the sound material in a flowing, sometimes quite precipitated tempo, and we make this mention according to the indication given in the score: Allegro moderato. Due to this interpretative version, the entire discourse gets other stylistic features, by its option regarding the tempo modification, the pianist leads the audience through a sound chaining of extensive deployment. The interpretative versions are also different in the case of approaching the chords of three sounds deployed on a tenth in the first bar: Elisabeth Leonskaja plays a softer arpeggio, whereas Paul Badura-Skoda opted for a very quick arpeggio version, imposed by the alert tempo. The harmonic-tonal evolution in the second phrase of the main theme, that also contains the inflexion towards tonality $B$ minor, is highlighted by both pianists through a somewhat fuller tone obtained by dosing a crescendo. The dynamic contrast that appears in the second segment of the main theme (mezzoforte-pianissimo- mezzoforte of bars 8-11) is evident in the interpretation given by the pianist Elisabeth Leonskaja, this one using the low dynamic in the moment of the imitatively transposing the motive at the left hand in the low pitch.

Elisabeth Leonskaja clearly delimitates the transition to the next form segment, the bridge, by dosing a low ritenuto in the end of the main theme. Despite the fact that the general dynamic of the first bridge segment is piano, Paul Badura-Skoda opts for the sound differentiation of the major-minor play in bars 21-24, choosing a reduced sonority for the A minor tonality. The serious and sober character of the secondary theme is more stressed by Elisabeth Leonskaja by choosing some more plentiful dynamics of mezzoforte and forte. Unlike Paul Badura-Skoda, the pianist carries out at the right hand accompaniment (bars 34-37) an expressive legato that follows the succession of triolets. The interpretative views of the two pianists are also different in terms of pedalling, Elisabeth Leonskaja preferring to raise the pedal on strokes two and four (bars 38-39), therefore the polyrhythm arising from the overlapping of ternary rhythm with the binary one becomes clearer. Both performers take into account the repetition sign in the end of exposition, the repetition being prepared through a small ritenuto in the last bar of the conclusion.

\section{Development}

From the dynamic point of view, the two pianists approach the development beginning in a different manner: Paul Badura-Skoda only keeps the piano dynamic indicated in the very beginning, the piano-mezzoforte-pianissimo dynamic contrast being replaced by a crescendo starting with bar 52 and culminating with the forte in bar 57. Elisabeth Leonskaja opts for a fuller dynamic even in the development beginning, with a quite decreased sonority in 
the case of the motive exposure at the left hand (bar 53). Paul Badura-Skoda impregnates the second phase with a more dynamic character due to the more faster tempo, one can also feel at him the difference between the non legato and staccato attack modes. In the last stage of the thematic processing area, we notice the concern of the pianist Elisabeth Leonskaja with details, the sixteenth in the punctuated rhythm is not a rushed one, the entire section being played in a much deeper sonority and calm atmosphere.

\section{Reprise}

In the reprise, the two pianists remain loyal to their own interpretative points of view approached in the exposition. There is a very big difference between the two interpretations of the first part (Elisabeth Leonskaja - 12'55", Paul Badura-Skoda - 6'58"), this being due to the different tempo, but most of all to the option embraced by the pianist Elisabeth Leonskaja to take into account the repetition sign marked by Schubert before the coda.

Second part, Andante (Elisabeth Leonskaja - 5'39", Paul Badura-Skoda 4'09")

\section{Exposition}

We also note here the tendency of the pianist Paul Badura-Skoda for a more dynamic and cursive tempos (4'09"), whereas Elisabeth Leonskaja adopts a more settled tempo (5'39") which allows her to highlight the cantability and lyrical nature of this part. In the playing of the main theme, the pianist makes use of a soft and very sensitive touch suggesting diaphanous states, in a reduced dynamics with small crescendos in order to prepare the accents in bars 10, 12 and 13. Paul Badura-Skoda dramatises the musical discourse by choosing a more diversified dynamical palette, reaching the forte through a strong crescendo carried out in bars 9-13. The accompaniment of the second theme has a delicate sonority in the interpretation of the pianist Elisabeth Leonskaja, this one following the melodic line exposed at the right hand with much refinement. Although Paul Badura-Skoda opts for a more consistent piano dynamic, he manages to keep the meditative nature of the secondary theme. Both pianists play the turn of bar 22 in a quiet and expressive manner, starting from the top note, therefore avoiding the repetition of the sound $F$. Due to the more settled tempo, Elisabeth Leonskaja succeeds in offering expression to small values of bars 37, 38 and 39 (the sixteenth and the two demisemiquavers), considering the punctuated rhythm written by the composer. Unlike Elisabeth Leonskaja, Paul Badura-Skoda does not take into account punctuated rhythm, choosing to lengthen the short values (the sixteenth and the two demisemiquavers) and playing them on the last quaver of the left hand triolet. The transition to the reprise (retransition) is thought in the same manner by the two performers, they start with a $p$ consistent tone, calmly following, in a soft decrescendo, the descending pace of the right hand soprano, supported by very quiet triolets that are dynamically decreased from the basso.

\section{Reprise}

While in the exposition Elisabeth Leonskaja prefers a reduced dynamics in the rendering of the main theme, in the reprise she follows the same 
conception as Paul Badura-Skoda, by dosing a crescendo that prepares the climax in forte of bar 56.The multiple Appoggiatura of bar 66 is differently interpreted by the two pianists, Paul Badura-Skoda providing this one with a rather pathetic nature, while Elisabeth Leonskaja plays it in an extremely quiet manner, both versions being equally interesting.

Third part, Allegro (Badura - Skoda 8'02", Elisabeth Leonskaja 7'27")

\section{Exposition}

If in the first two parts Paul Badura-Skoda prefers a quicker tempo than Elisabeth Leonskaja, in the last part the pianist approaches a more settled tempo (Paul Badura - Skoda 8'02", Elisabeth Leonskaja 7'27") using it to highlight its dancing nature. The beginning of this part is played by Paul Badura-Skoda through a small settlement on the first sixteenth of the anacrusis and a incisiveness of the staccato quavers, whereas Elisabeth Leonskaja comes with a different version: the anacrusis meaning is towards first beat and the sonority of quavers is more rounded. The accents of bars 11, 12, 15 and 16 are achieved by Paul Badura-Skoda by small settlements, unlike Elisabeth Leonskaja that ignores them. According to Paul Badura-Skoda, the dynamic contrasts (fortepiano, piano-fortissimo) and forzandos of the bridge are clearer, therefore managing to create a much more energetic atmosphere compared to the version of the pianist Elisabeth Leonskaja.

The secondary theme is given elegance and refinement in the version of the pianist Paul Badura-Skoda, by choosing a little more settled tempo that allows him to underline its expressivity with a help of a delicate touch in piano and pianissimo. In the second component of the secondary thematic group, Elisabeth Leonskaja ignores the numerous forzandos of the left hand basso, whereas Badura-Skoda transfers them to the right hand as well in order to intensify their sound effect. In the exposition of the melody, the two pianists use the right pedal in an economic manner to be able to differentiate the two attack modes, legato - staccato.As it happened in the first part, both performers take into account the repetition sign in the end of exposition.

\section{Development}

Elisabeth Leonskaja gives the development a more agitated nature, due to the quicker tempo, as well as to the dosing of an accelerando in bars 92-103. By choosing a more settled tempo, Paul Badura-Skoda succeeds in creating an extended dynamic palette starting with delicate pianissimo sonorities and culminating in forte, therefore obtaining special sound effects. Although the last phase of the development is built in piano, the pianist offers an interesting interpretative version marking the total evolution $B$ minor - $A$ major, by dynamic fluctuations of crescendo and decrescendo, the climax being the highlighting in forte of the tonality A major II $\downarrow$.

\section{Reprise}

The transition towards the reprise is played in a different way by the two pianists: Paul Badura-Skoda prepares this section through a small ritenuto and a soft settlement on the first sixteenth of the anacrusis; Elisabeth Leonskaja keeps the alert tempo in the end of the development, the connection with the reprise 
being achieved with no marking of its beginning. The new accents added by Schubert in the beginning of the multiple anacrusis of bars 123 and 131 are ignored by Elisabeth Leonskaja, these being achieved solely by Paul BaduraSkoda through small settlements.

The coda is played with much sensitivity by both pianists in a delicate manner, highlighting the beauty of the main theme. The sound effect created by the piano-fortissimo dynamic contrast in the end of the sonata, is at its maximum according to Paul Badura-Skoda through the dosing of a ritardando and use of the sourdine in bars 214-215. In this part, the interpretative version suggested by Elisabeth Leonskaja focuses in general on the virtuosity side, whereas Paul Badura-Skoda approaches the musical discourse with a large amount of grace, highlighting the subtle harmonic relationships and expressivity of the melodic lines.

\section{Bibliography}

1. *** New Grove Dictionary of Music and Musicians, second edition (2001), Macmillan Publishers, London

2. Badura-Skoda, Eva, Branscombe, Peter, (2008), Schubert Studies: Problems of Style and Chronology, Cambridge University Press, Cambridge

3. Berger, Wilhelm Georg, (1987), Teoria generală a sonatei, Editura Muzicală, Bucureşti

4. Black, Leo, (2003), Franz Schubert, Musik and Belief, The Boydell Press, Suffolk

5. Bughici, Dumitru, (1974), Dicţionar de forme şi genuri muzicale, Editura Muzicală a Uniunii Compozitorilor, Bucureşti

6. Deutsch, Otto Erich, (1958), Schubert. Memoires by his friends, The Macmillan Company, New York

7. Krause, Andreas, (1996), Die Klaviersonaten Franz Schubert, Form-GattungÄsthetik, Bärenreiter Verlag, Kassel

8. Montgomery, David, (2003), Franz Schubert's music in performance: compositional ideals, notational intent, historical realities, pedagogical foundations, Pendragon Press, Maesteg, Mid Glamorgan

9. Neuhaus, Heinrich G., (1962), Despre arta pianistică, Editura Muzicală a Uniunii Compozitorilor, Bucureşti

\section{Scores:}

1. Schubert, Franz, Klaviersonaten. Band I, Urtext, G. Henle Verlag, Munich

Discography:

1. Elisabeth Leonskaja, Schubert Piano Sonatas No. 13 (D 664) \& No. 20 (959), Teldec Classics International GmbH, CD 0927408322

2. Paul Badura-Skoda, The Complete Piano Sonatas. Volume II: D 568, D 571/604/570, D 575, D 613/612, D 625/505, D 664, RCA Victrola, CD VICS 6129 (3 Record Set)

\section{Web pages:}

1. http://en.wikipedia.org

2. http://www.badura-skoda.com

3. http://www.leonskaja.com 